\title{
Analyzing Spatial Structure of Traditional Houses in Old Towns with Tourism Development and Its Transformation toward Sustainable Development of Residential Environments in Hexia Old Town, in China
}

\author{
Rie Nomura ${ }^{1, *}$, Siyuan Shan ${ }^{2}$ and Suguru Mori ${ }^{1}$ \\ 1 Faculty of Engineering, Hokkaido University, Sapporo 060-8628, Japan; suguru-m@eng.hokudai.ac.jp \\ 2 Shanghai Urban Construction Design \& Research Institute (Group) Co., Ltd., Shanghai 200125, China; \\ samssy@hotmail.com \\ * Correspondence: nomurarie@eng.hokudai.ac.jp; Tel.: +81-11-706-6264
}

Received: 20 September 2018; Accepted: 19 October 2018; Published: 22 October 2018

\begin{abstract}
This study elucidates the spatial structure of traditional houses, and its transformation toward sustainable development of residential environments in old towns that are currently the focus of tourism development initiatives. Hexia old town in Huai'an District, China, was chosen for this study involving a field survey, questionnaire survey, and interviews. Data analysis identified three periods of residential transformation and three patterns of the residential transformation process. In all cases, there was low awareness of building conservation measures and lack of tourism development by the government, which has translated into ongoing residential transformations according to the demands of daily life. However, in the interests of tourism development, some businesses have started making use of vacant residences and traditional homes, and the relative proximity to work and home imply sustainability of residents' lifestyles under these conditions. An improvement plan for an old town requires a thorough understanding of the circumstances surrounding residential modifications executed by residents, the problems faced in the living environment, as well as efforts to increase the residents' awareness of the issue of sustainable living in that old town.
\end{abstract}

Keywords: spatial structure; traditional house; tourism development; China; living environment

\section{Introduction}

\subsection{Background and Purpose}

This study focuses on Hexia old town in Huai'an District, China, which currently is the subject of tourism development efforts. As part of consideration of how to enable residents to continue living in the historic district, the circumstances around spatial construction and resulting transformations will be examined, with particular attention to resource usage and lifestyle maintenance issues. The study aims to elucidate the spatial structure of residences and its transformation.

Various cities across China have already benefited from acknowledgment and protection of their heritage sites. In particular, areas with historical buildings in good condition and maintained with a certain level of consistency have come to be referred to as "old towns", and targeted protection measures for individual buildings have been implemented with a view to protect broader areas [1]. In the 1980s, a large-scale protection plan was implemented in "Zhouzhuang old town", improvement as it increasingly came to be considered for its potential as a tourist destination. From 1989, tourist inflow 
with accompanying significant economic impacts increased [2,3]. In addition, the old town of Lijiang in Yunnan Province, China, was registered as a world heritage site by UNESCO (United Nations Educational, Scientific and Cultural Organization) in 1997, in response to which tourists from all over the world, including China, came to visit the town. Against this backdrop, many Chinese cities are using historical areas to attract tourists and develop their tourism industries [4]. However, economic benefits from tourism are being prioritized, and in some cases, new commercial facilities featuring a "historical atmosphere" are being constructed, turning the historic district into something similar to a theme park. Such developments are accompanied by a feeling of loss of historical and cultural value $[5,6]$. Furthermore, in cases where tourism development leads to displacement of residents or brings about changes in their livelihood, the lives of residents, their relationships with neighbors, and maintenance of culture have been jeopardized [7].

Urban development and protection of cultural heritage and concerns, such as tourism of cultural heritage sites and maintenance of resident's lifestyles are not only limited to China, but are also being discussed worldwide. Especially in developing countries, both improvement of infrastructure and protection of cultural heritage pose a challenge. In European countries, tourism development has had a negative impact on the lives of people living in historic districts [8,9]. In China, the perspective is shifting from urban area and tourism-related development that prioritizes the economy to sustainable heritage conservation and residents' lifestyle sustainability [10]. In protection of historic districts, urban development planning, and tourism development planning, many studies note the need for cooperation with a diversity of stakeholders, including residents, and due consideration of residents' level of awareness [11-13].

In "National Famous Historical and Cultural Cities" published in 2003 by The State Administration of Cultural Heritage, the appeal of old towns across the nation with long respective histories were reevaluated. Tourism industry was acknowledged as a source of income for residents, and measures to develop and improve old towns were implemented. However, to protect, develop, and improve old towns, and to maintain and improve the residents' living environments, several challenges still need to be overcome.

\subsection{Research Status}

Studies on old towns in China mainly focus on three points—characteristics of preservation systems and discussion, models of tourism development and challenges, and spatial characteristics of old towns, living styles, and transformation. A series of studies on preservation systems entitled "Important National Historical and Cultural Cities and Towns" has been published [14,15]. The preservation systems are based on plans appropriate to the relevant time periods, and are transitioning from targeted protection of cultural heritage to systematic comprehensive preservation $[14,15]$. This study examines the town preservation plans that conserve entire villages, which are the most common for the preservation of cultural properties in China, and which focus on substantially reducing damage to the historical environment. It should be noted, however, there is lack of clarity regarding interpretation of configuration and structure of traditional spaces within the preservation areas; inheritance of regional culture; resident participation; and involvement of regional organizations.

Concerning tourism development models and their challenges, initially, various government-led tourism development and improvement initiatives were developed promising benefits in terms of economic impacts; however, various development models were created thereafter focusing on the value of the preservation of buildings and inheritance of cultural and historical properties [2]. In the first model, the government formulated preservation development plans in which the residents could actively engage in commercial activities. In the second model, the government relocated the local residents, acquired $80 \%$ or more residences, established tourism ventures, and invested in its stocks. This model resolved the conflict between commercial activities by local residents and the preservation of traditional buildings. In the third model, the government repaired, restored, reproduced traditional buildings, and transferred the management rights related to tourism development to 
private businesses. However, all these models did not adequately balance between guaranteeing infrastructure for continual residence, residents' production activities, and preservation of traditional buildings and culture. While tourism development positively impacted economic development, concerns, such as outflow of youth, large companies locating outside the area holding the management rights, surrounding urban area development that isolates the preservation areas, and loss of seamless interaction with the surrounding environment have also been raised $[2,3,16,17]$. To convert traditional areas to tourist destinations, emphasizing the importance of preservation of cultural and historical heritage of the region, as well as dynamic preservation measures that consider the modern lifestyle of the residents have been raised as effective [17].

Consequently, the effectiveness of and concerns related to historical buildings preservation systems and plans are being acknowledged, in particular the historical value, as well as the importance of improving the residents' living environments are emphasized. Under the concept of "regeneration" of buildings, specific renovation techniques and designs for historical buildings are being considered [18]. In addition, an earlier study analyzed the impact of tourism on residents through understanding of "current usage" of old areas [19]. Registered as a world heritage site, the case of the historic district in Lijiang in Yunnan Province, China provides an example of the importance of coming to a thorough understanding of the situation and issues using a field survey. To this end, the present study examines the level of awareness of these issues. However, transformation of traditional private homes requires taking into account complex factors, such as social background in addition to tourism-related factors.

Therefore, for areas that have become the focus of tourism development initiatives, this study focuses on the spatial structure of traditional residences to understand the long-term changes, including the impact of policies since the 1950's. To examine policies that promote continuity of residence in the relevant areas while protecting the traditional townscapes, this study attempts to discover changes in residents' day-to-day needs, as well as policy response under government-led preservation and tourism development plans through an examination of changes in the spatial structure of traditional houses.

\section{Research Area}

The old town of Hexia in Huai'an City is located in the central western part of Jiangsu province, China, $400 \mathrm{~km}$ northwest of Shanghai (Figure 1). The existing town structures were built during the Ming and Qing Dynasties. The townscape is characterized by the side-by-side residences facing the streets (Jie) and lanes (Xiang).

\subsection{Historical Changes to Hexia Old Town}

According to historical records, the ancient "Old town Hexia" [20] was established along the canal that connects Yangzi River and Huai River in 486 BCE. Since its completion in 605 BCE, the canal has played an important role as a food transportation route with military bases, and was used to ship supplies mainly to the north. Though it continued to flourish as a commercial city until Northern Song Dynasty, it was devastated during a period of military conflict.

During the Ming and Qing Dynasties, the water-bound transport function was restored and the old town began to flourish again. Salt merchants moved to the old town, and residences, assembly halls, gardens, and gateways (Pai fang) were constructed. In addition to streets (Jie) and lanes (Xiang), the historical area of Huai' an District as it stands today was created. However, toward the end of the Qing Dynasty, salt production and commercial sites were relocated elsewhere, and thus reducing the significance of the canal's use for transport. Owing to several military conflicts, the old town began to decay accompanied by a decline in the number of commercial establishments.

\subsection{Present-Day Hexia Old Town}

In 2002, the Chinese Construction Department designated Hexia old town one of 30 "Important Historical Conservation Areas" in China [16]. Then, in the same year, Huai'an City Government 
formulated the "Huai'an Historical and Cultural Famous Town Conservation Plan (2001-2020)", which formed the basis for tourism development (subsequently revised in 2012, and currently being implemented as a plan until 2030) [21]. Furthermore, in 2006, the People's Republic of China State Council designated the old town as a "Major Historical and Cultural Site Protected at the National Level".
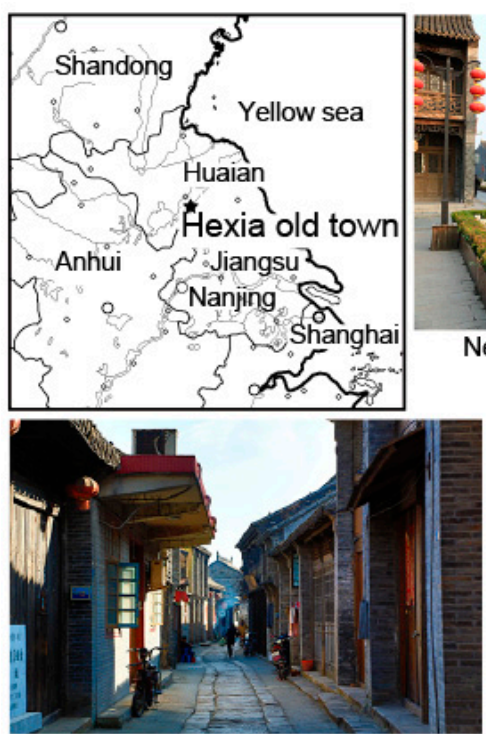

Street landscape

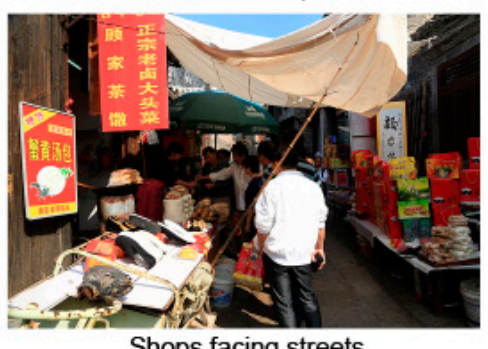

Shops facing streets

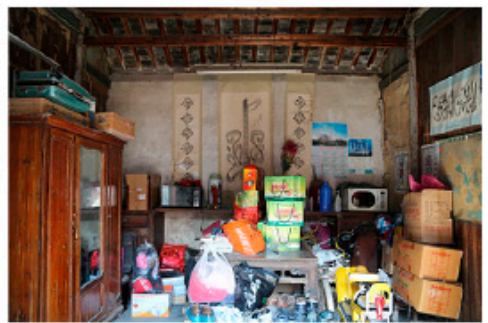

Inside of a traditional house

Legend

(1) House of Hua lane

1 House of Huzui street

- Border of the historical area

$\square$ New commercial buildings

The subject of investigation

$\square$ Questionnaire survey respondent

Interview survey respondent
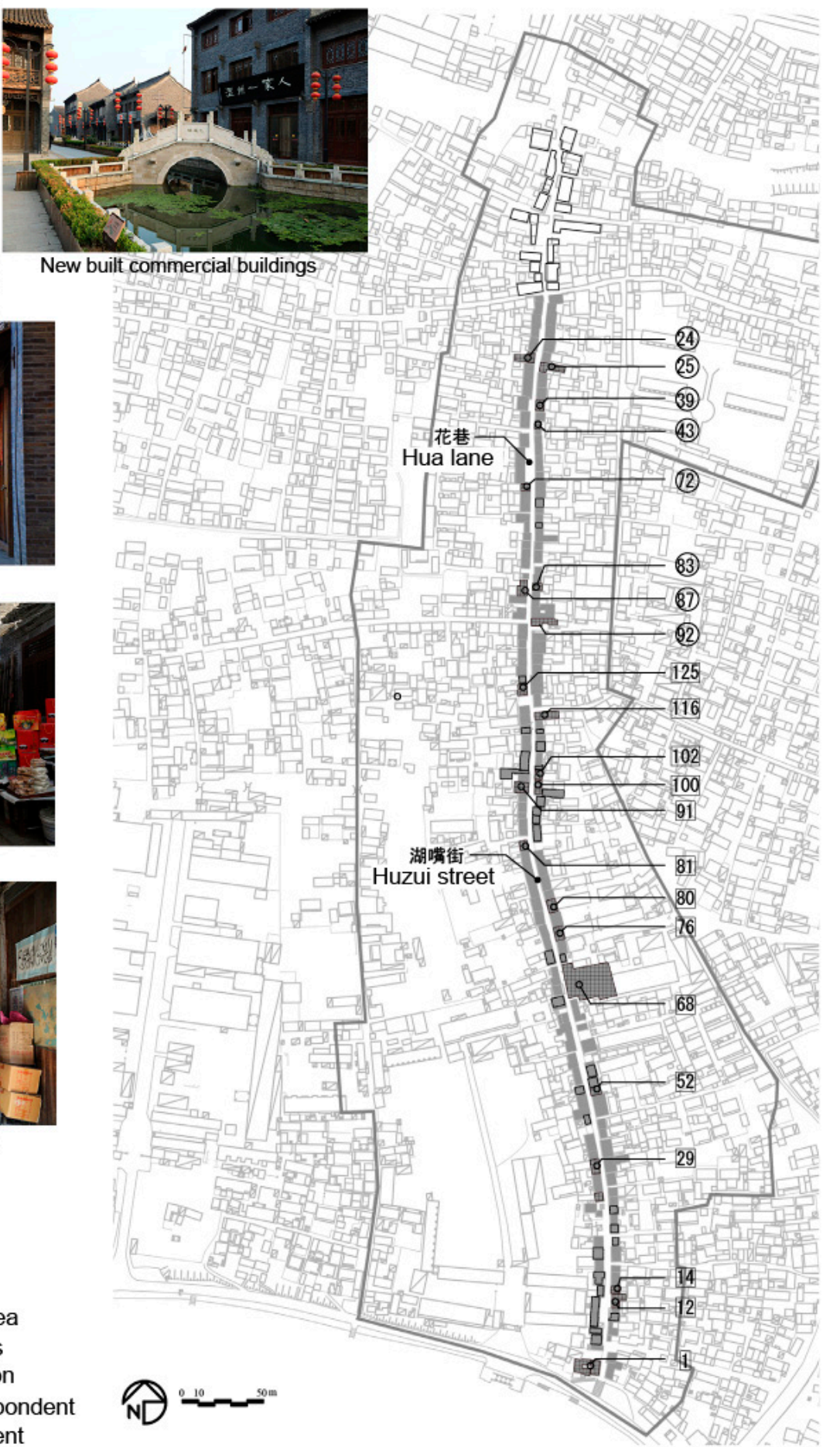

Figure 1. Research area.

The tourist sites in Hexia old town are mainly located at the center of the town and the old town structures constructed during Ming and Qing Dynasties are still standing. The old town stretches 
$2.5 \mathrm{~km}$ east to west, and $1 \mathrm{~km}$ north to south, with an area of about $2.5 \mathrm{~km}^{2}$. The population of the town is about 12,000. Huzui St. (Huzui jie) and Hua Ln. (Hua xiang) that cut across the center of the area intersect with 105 streets (Jie) and lanes (Xiang). There are many old residences that need repairs, but are neglected due to the residents' financial constraints. Establishments facing the streets sell day-to-day necessities to these residents and provide daily living related services.

In 2004, a summary of the "Hexia old town Historical and Cultural Area Conservation and Improvement Plan" was formulated. In 2007, the government started renovating the residences facing Hua Ln. This was part of the Hexia old town preservation and improvement plan, which mainly included sewer maintenance of Hua Ln., renovation of the residential façade, an installation of street lights. Huzui St. residential improvement work and renovation of the northern entrance are ongoing [22]. In 2016, the government published "Hexia old town Historical and Cultural Area Conservation Plan" [23].

As such, historical and regional values of Hexia old town was acknowledged by Chinese government, and local governments and specialized agencies formulate protection and improvement plans and are promoting tourism development. The development of tourism are presently in progress, and by understanding what is happening to the residents during the development process and identifying issues, their findings could be utilized in the next plan. Furthermore, we can continuously monitor the process of changing needs of residents over a long period of time, and the impacts of conservation, renovation, and tourism development. For these reasons, we selected Hexia old town as the subject of our survey.

\section{Materials and Methods}

First, to understand the characteristics of the spatial structure of residences and the lifestyle of the residents in Hexia old town, a field survey, a questionnaire, and an interview were conducted. The study presented the characteristics of the modification methods and then plotted modifications made by residents on a time-line. In addition, the study, which is aimed at promoting sustainability of living and, in turn, improving the historic district, examined the characteristics of the spatial structure and modification processes used by residents and analyzed the use of residences and attempts at maintenance.

\subsection{Selection of the Subject of the Study}

Hexia old town was the subject of tourism development initiatives since 2007 and was opened to public tourism in 2011. Improvement of Huzui St. and Hua Ln. was the first step in the old town improvement plan. As of October 2014, these were the only locations with progress in or completion of improvement efforts. There are 215 traditional houses along Huzui St. and Hua Ln. Residences designated for preservation of their street-facing façades were repaired using subsidies. Along with these repairs, residents also modified the interiors of their residences. With the influx of tourists, local specialty and souvenir shops began to appear, which led to expanding commercial activities. Continuing impacts on the townscape due to the lifestyles of residents and tourism is expected.

The target of this study is 215 residences facing Huzui St. and Hua Ln (Figure 1).

\subsection{Survey Method}

To understand the spatial structure of residences and their transformation in the old town, the following three surveys were conducted.

(1) Literature survey: Literature dealing with ordinances by the city and protection plans was collected.

(2) Questionnaire: A questionnaire was conducted in September 2014. All 215 residences facing Huzui St. and Hua Ln. were given a questionnaire, which yielded 64 valid responses (i.e., a recovery rate 
of $29.8 \%$ ). The questionnaire items included family structure of residents, the number of residents, history of residence, the ages of the residences, spatial structure, area, and modifications.

(3) Interviews and measurement survey: Interviews and measurements were conducted in October 2014 for 22 residences based on informed consent. Residents were interviewed on the transformation process, including repairs and reconstruction implemented by residents themselves, and the measurements were taken both inside and outside of the residences.

\section{Results}

\subsection{Overview of the Residents and Residences in Hexia Old Town}

Below is an overview of the residents and residences in Hexia old town based on the questionnaire and interview results.

First, the questionnaire results show that, on average, there are three members in a family living together. Though single persons or nuclear families were more common, a few families had up to three generations living together. Moreover, $56.3 \%$ of residents lived with senior citizens, while $35.9 \%$ of residents lived with minors (Table 1). Age distribution data of the households targeted for the interview showed that $34.8 \%$ of residents are in their $60 \mathrm{~s}$ and $70 \mathrm{~s}$, indicating that the town is aging.

Table 1. Basic information of the respondents (Questionnaire).

\begin{tabular}{cccc}
\hline Variables (Questions) & Category & Response Total & Percentage (\%) \\
\hline \multirow{2}{*}{ Street } & Fuzui street & 45 & 70.3 \\
& Hua Lane & 19 & 29.7 \\
\multirow{2}{*}{ Gender } & Male & 27 & 42.2 \\
& Female & 37 & 57.8 \\
\hline \multirow{2}{*}{ Age } & 30 years and under & 5 & 7.8 \\
& 31-59 years & 30 & 46.9 \\
& 60 years and above & 29 & 45.3 \\
\hline Living with senior citizens & Yes & 36 & 56.3 \\
(over the age of 60) & No & 28 & 43.8 \\
\hline Living with minors (under the & Yes & 23 & 35.9 \\
age of 19) & No & 41 & 64.1 \\
\hline
\end{tabular}

The type of residence ownership was as follows-67.2\% inherited, $21.9 \%$ purchased, and $7.8 \%$ rented. Most residences were established before 1970s (65.6\%), and only $10.9 \%$ of residents had begun living in the town since 2001 (Table 2).

With respect to the layout of the residences, $42.2 \%$ are smaller than 2LDK (2 Bedrooms; Shi in Chinese +1 Living/Dining room + Kitchen; Ting in Chinese), while $57.8 \%$ were larger than 3LDK (3 Bedrooms + 1 Living/Dining room + Kitchen). A comparison of the total floor areas of the residences of the interviewed households shows that the smallest was $11 \mathrm{~m}^{2}$ and the largest was $418 \mathrm{~m}^{2}$; in other words, there were a wide range of floor areas.

With regard to impacts of tourism development, the following was observed $-32.8 \%$ of residents were self-employed, among which $47.6 \%$ had been in business since 1970 s, while $23.8 \%$ opened their businesses after 2001. Customers of self-employed businesses are gradually shifting from local residents to tourists, and two of the stores are exclusively targeting tourists (Table 3). However, along with increasing tourism, four residences had modified the types of businesses, among which three had renovations, additions, or changes made to the layouts. Regardless of being in business or not, $70.3 \%$ of the overall residences made changes to their floor plans; of these, about half of them implemented reconstruction work for their premises since 2007 when tourism development began (Table 4). As a result, the spatial structure of residences is assumed to have changed. 
Table 2. Situation of the residence (Questionnaire).

\begin{tabular}{cccc}
\hline Variables (Questions) & Category & Response Total & Percentage (\%) \\
\hline \multirow{3}{*}{ Residence ownership } & Own house (Inherited) & 43 & 67.2 \\
& Own house (Purchased) & 14 & 21.9 \\
& Rented house & 5 & 7.8 \\
& N.A. & 2 & 3.1 \\
When have you started & Before 1970 & 42 & 65.6 \\
living here? & 1971-1980 & 2 & 3.1 \\
& 1981-1990 & 4 & 6.3 \\
& 1991-2000 & 9 & 14.0 \\
& After 2001 & 7 & 10.9 \\
\hline \multirow{2}{*}{ Layout of the residence } & 1DK (1 Bedroom + Dining + Kitchen) & 8 & 12.5 \\
& 2LDK (2 Bedrooms + Living/Dining & 12 & 18.8 \\
& rodroom + Living/Dining & 7 & 10.9 \\
& 3LDK (3 Bedrooms + Living/Dining & 6 & 9.4 \\
\hline
\end{tabular}

Table 3. Impacts of tourism (Questionnaire).

\begin{tabular}{cccc}
\hline Variables (Questions) & Category & Response Total & Percentage (\%) \\
\hline $\begin{array}{c}\text { Are you doing business } \\
\text { in the house? }\end{array}$ & Yes & 21 & 32.8 \\
& No & 43 & 67.2 \\
When have you started & $1971-1980$ & 10 & 47.6 \\
doing the business? & $1981-1990$ & 0 & 0.0 \\
& $1991-2000$ & 2 & 9.5 \\
& After 2001 & 3 & 14.3 \\
& N.A. & 5 & 23.8 \\
& Local residents & 1 & 4.8 \\
\hline \multirow{2}{*}{ Target customers } & Tourists & 9 & 42.9 \\
& Both & 10 & 47.5 \\
\hline Did you change the type & Yes & 4 & 19.0 \\
of business? & No & 17 & 81.0 \\
\hline
\end{tabular}

Table 4. Modification work (Questionnaire).

\begin{tabular}{cccc}
\hline Variables (Questions) & Category & Response Total & Percentage (\%) \\
\hline Did you make changes to & Yes & 45 & 70.3 \\
the floor plan? & No & 19 & 29.7 \\
\hline Did you make changes to & Yes & 24 & 37.5 \\
the layout of furniture? & No & 40 & 62.5 \\
\hline \multirow{2}{*}{ When did you change } & Before 2006 & 17 & 37.8 \\
the floor plan? & After 2007 & 27 & 60.0 \\
& N.A. & 1 & 2.2 \\
\hline Do you know the & Yes & 5 & 7.8 \\
conservation plan? & No & 59 & 92.2 \\
\hline
\end{tabular}




\subsection{Analytical Perspective on the Residential Modification Processes}

\subsubsection{Residential Basic Structure and Classification}

The basic residential spatial structure in Hexia old town is defined according to the descriptions and actual measurements in "Hexia old town (Hexia Guzhen)", which is a courtyard style commonly seen in traditional Chinese residences, rectangular in shape and opening from front to the back (Figure 2). The gate house (Lin jie) is a room that faces the street, as the name suggests. It is the boundary between the outside and inside of the residence, or the boundary between public and private. The side halls (Xiang fang) are rooms located on both sides of the courtyard. These rooms have functions, such as kitchen, laundry room, and storage, and if there are several household members, these rooms may be used as a bedroom. The main hall (Zheng fang) is located at the back of the courtyard and contains the living room and bedrooms. Generally, this is used by the head of the family.
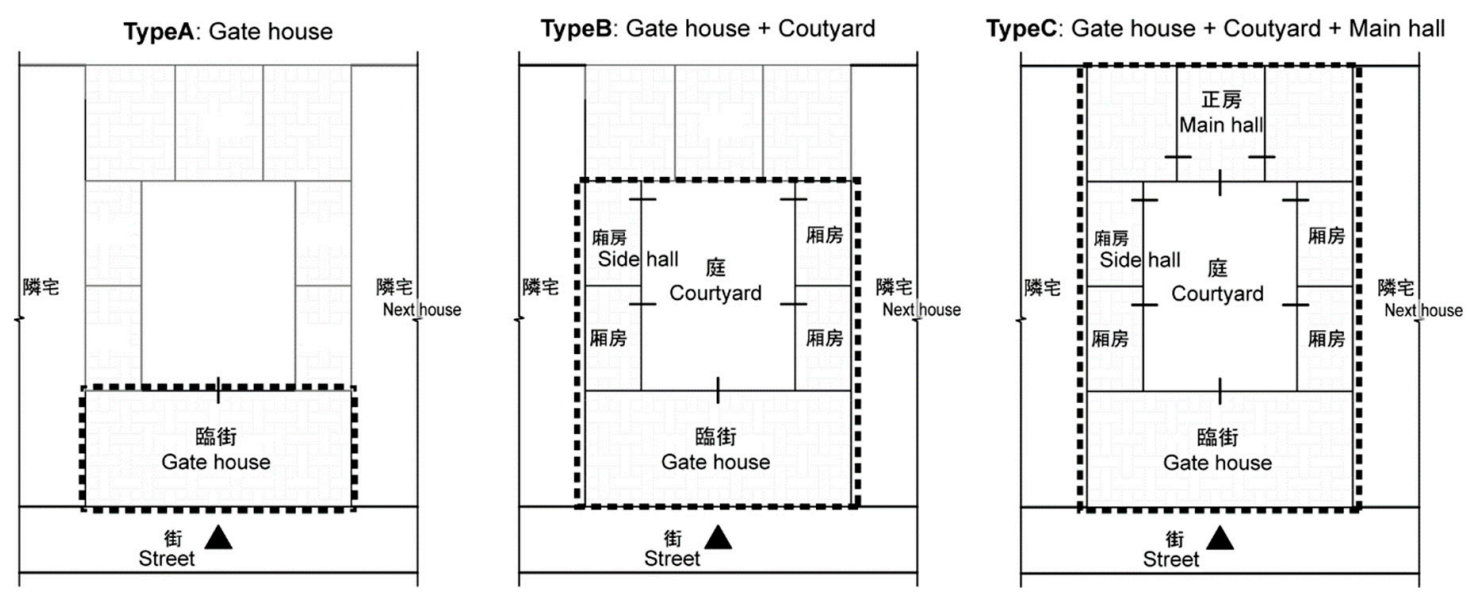

Figure 2. Basic layout and type of the traditional residence.

Type A: It only has a gate house facing the street and there is no courtyard.

Type B: It consists of a gate house, as well as a courtyard. The kitchen may be in the courtyard. There are two types of room structures within this classification. The first type has a living room followed by bedrooms in the gate house, with the kitchen, bathrooms, and storage in the courtyard. The second type has a living room in the gate house, with a bedroom facing south at the corner of the courtyard, which is surrounded by the kitchen, bathroom, and storage.

Type C: It is similar to the basic form, comprising a gate house, courtyard, and main hall. There is a side hall with the courtyard featuring a variety of functions. There are two types of room structures based on whether the residence functions as a shop. If it has a shop, the gate house is used as a shop, with living space, such as bedrooms, a living room, the kitchen, and courtyard, located at the back. If there is no shop, the gate house contains the living room and a space, such as an entrance that connects with the outside. The kitchen, bathroom, storage, and even the side hall that could be used as the bedroom for the head of the household or living room are situated in the courtyard.

Type D: This type has no relationship to the spatial structure of the basic form. In some cases, it has only the shop. Residents may have their own home in another part of the town and commute to this shop.

\subsubsection{Definition of the Residential Modification Method}

First, the residential modification methods observed in the survey can be classified into five types.

"New construction(N)" refers to building a new residence by demolishing an existing one. A residence or a part of the residence is built by assuming ownership of (purchasing) the adjacent property. 
"Expansion (E)" refers to building a separate building on the same property, for example, building a second story onto an existing bungalow.

"Reconstruction $(\mathrm{RC})$ " refers to removing a part of a residence, building a residence with similar usage, scale, and structure, and this includes repairs to the interior.

"Reduction (RD)" refers to forcibly reducing or removing part of a residence based on a notice or ordinance from the local government. This includes removing a floor from a two-story building.

"Change in function $(\mathrm{C})$ " refers to changing the function of a room.

\subsubsection{Division of Period Based on the Political Landscape}

The characteristics of residential transformation of Hexia old town identified in this study are divided into three periods:

The Government levy period (1950-1969): This period comprises the "Up to the Mountains and Down to the Countryside Movement" and the "Great Leap Forward", which severely impacted China. The Up to the Mountains and Down to the Countryside Movement led to a massive movement in population. With more and more youth moving to the old town, new residences were constructed through land purchases once the existing residences were completely demolished. The Great Leap Forward, however, was noted for levies on residences, turning them into public assets.

Free construction period (1970-2006): Throughout the government levy period, the old town entered a relatively stable period. There were no changes due to policy requirements, but the period was characterized by economic development across China and changes in the family structure of residents in the old town. Residential modifications in response to the needs of the residents rapidly increased, and all 22 residences that were targeted for interviews had been reconstructed, expanded, or changed some function during this period.

Governmental development period (2007-present): In 2007, as part of a Huai'an District cultural tourism development initiative, an improvement plan was implemented and private companies started construction. In the government survey, residences along the street were classified into four types based on the maintenance of traditional construction styles, and residential modifications made by residents were deemed to have an impact on improvement of tourism sites. "Huai'an City Hexia old town Historical and Cultural Famous Town Conservation and Improvement Plan" defined the modification method, and placed a ban on new construction and reconstruction by individuals. Twenty-two of the surveyed houses had either been reconstructed or had changed functions during this period.

\subsubsection{Classification of Residential Modification Patterns}

On grasping the process of modifications for the particular residences to note the modifications made to the residences during the three different periods, we classified similar processes on the basis of the following patterns.

Pattern I included reduction or expansion/reconstruction/change in function or reconstruction/ change in function (RD-E/RC/C-RC/C).

Pattern II included new construction or expansion/reconstruction/change in function or reconstruction/change in function (N-E/RC/C-RC/C).

Pattern III included expansion/reconstruction/change in function or reconstruction/change in function (X-E/RC/C-RC/C).

During the government levy period, residences followed Pattern I with reduction, Pattern II with new construction, and Pattern III with no changes. In all the patterns, expansion, reconstruction, or change in function was implemented during the free construction period. The governmental development period saw incidences of reconstruction or changes in function. 
4.2.5. Response to Tourism Observed in the Residential Transformation Process and the Relationship with Spatial Structure

Plotting residential spatial structure types A-D on the vertical axis and residential modification patterns I-III on the horizontal axis, the categories for the relationship between spatial structure and transformation process were extracted. In theory, there are 12 categories, but in this survey only seven were observed (Figure 3). On the basis of the residential modification patterns, the characteristics of residential transformation and response to tourism were analyzed, focusing on the spatial structure type of residences (Figure 4).

(1) Pattern I: A pattern where reduction was made during the government levy period

Eight cases fit Pattern I. In all the eight cases, a part or the entirety of residences was largely modified during the government levy period.

Case I-B "H St. 80": The case "H St. 80", whose spatial structure fits Type B, has been running "Taoist paper art (Zhizha)" for generations. The head of the household is the 11th owner of the business. During the 1960s, about $400 \mathrm{~m}^{3}$ courtyard space was levied and converted to a factory site.

With reduction of residences, it was difficult for households to hold multiple generations. Therefore, part of the family moved outside of the town. The remaining family created a private space by dividing the gate house and expanding the entrance. During the governmental development period in 2007, interiors of the residences that had aged were renovated. At that time, the kitchen and the shop with old gabled roof, windows, and floor finish were retained so that tourists could explore the construction style of Ming Dynasty. Though the traditional spatial structure was destroyed, due to reduction work and subsequent modifications by further dividing the public and private spaces within the gate house that faces the street, the family living space was secured and the response to tourism was managed.

Case I-C "H Ln. 24": "H Ln. 24" is a residential structure of Type C. It had a traditional spatial structure with a gate house, a courtyard, a kitchen, and a main hall in the 1960s. However, as the household became independent, the interior of the residence was divided into three segments and walls were built; thus, the family lived in the northern-most one-third of the residence. At this time, the family started a general store in the gate house. Subsequently, with an increase in the number of family members, living space became insufficient. Thus, the family moved, and the residence was used as a storage space. Practically, the residence was vacated. With the new emphasis on tourism development in 2007 , the family repaired the interiors to maintain the aging residence. With the opening of the old town to the public in 2011, the family reopened the general store and is currently selling homemade local cuisine as souvenirs in addition to day-to-day necessities. Since they have a separate residence, comfort as a living space is not a concern, and the residence with its traditional residential structure is used as a place of business to benefit from the tourism activities.

Case I-D "H Ln. 87": "H Ln. 87" has a spatial structure of Type D. It only has a shop that is well known for its handmade tofu. The family resided in a separate house $20 \mathrm{~m}$ away. During the 1950s, the government levied the shop, which was lent to another person. When the father, the head of the household, passed away, the tofu shop was shut. In the 1990s, the family repurchased the shop and opened a general store. With the emphasis on tourism development in 2007, they purchased a hut next door and used it as a bedroom. They also borrowed their neighbors' kitchen space to cook their meals. The family appeared to have made an effort to bring the place of work and living closer with the help of a minimum facility.

In cases fitting Pattern I that experienced large-scale residential modifications during the government levy period, along with changes to the family structure and business of the households, there were notable spatial transformations, such as business and living spaces being separated. However, by utilizing partially remaining traditional spatial structure, all other cases are flexibly adjusting to the tourism. 


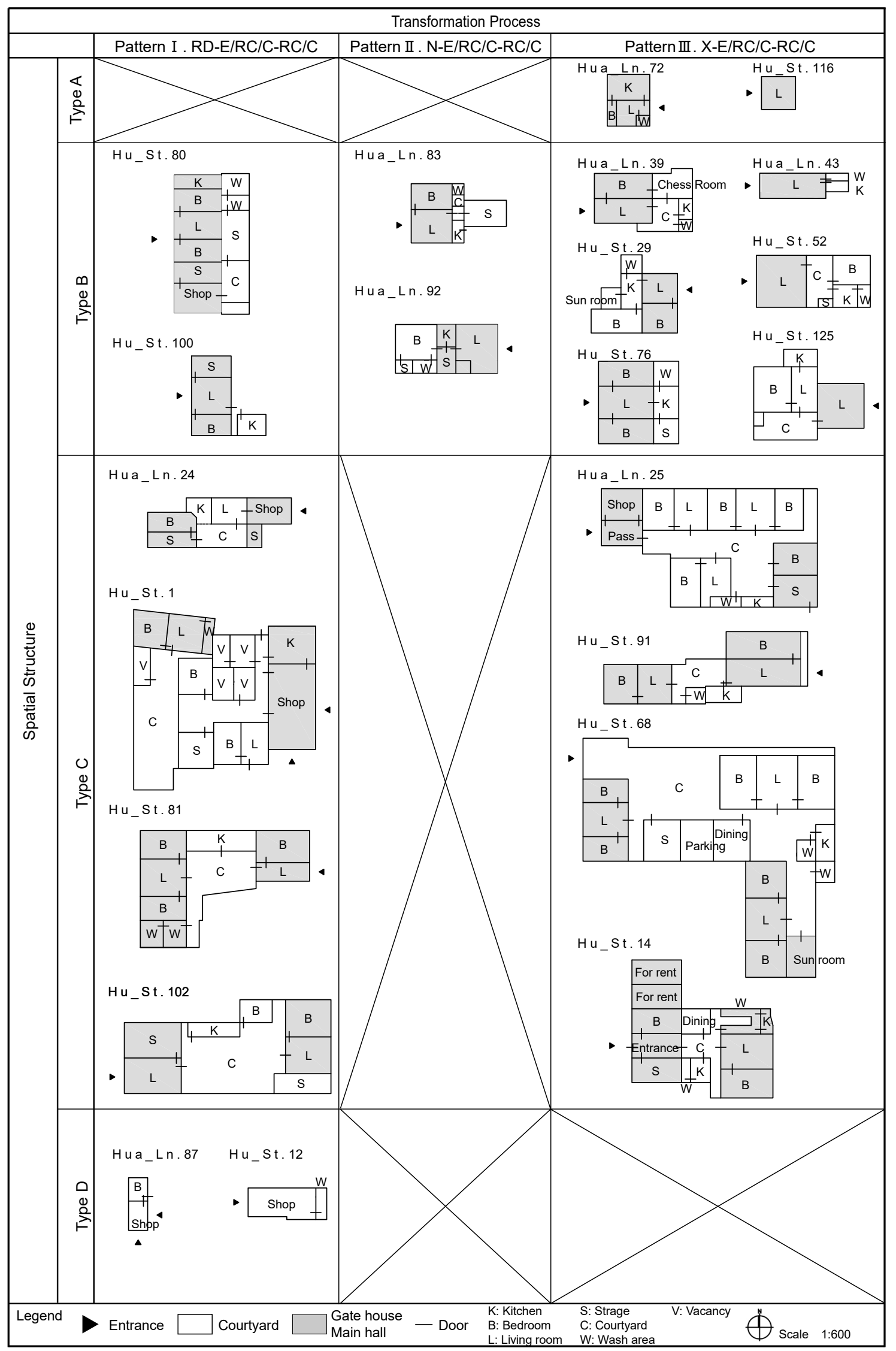

Figure 3. Categories of the residential transformation process and the spatial structure. 


\begin{tabular}{|c|c|c|c|}
\hline & $\begin{array}{c}\text { The Government levy } \mathrm{p} \\
(1950-1969)\end{array}$ & $\begin{array}{r}\text { Free constructi } \\
(1970-20\end{array}$ & (2) \\
\hline $\begin{array}{l}\text { I-B } \\
\text { H St. } 80 \\
\underset{60 \mathrm{~s}}{\triangle} \underset{60 \mathrm{~s}}{\mathrm{O}}\end{array}$ & $\begin{array}{l}\text { During the } 1960 \text { s, the courtyard } \\
\text { pace was levied and converted to } \\
\text { a factorysite }\end{array}$ & $\begin{array}{l}\text { Extended the } \\
\text { bathroom } \\
\text { The remaining } \\
\text { family created a } \\
\text { private space }\end{array}$ & 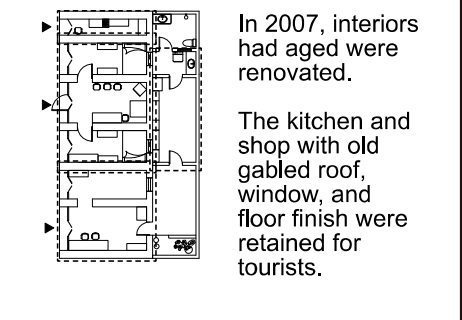 \\
\hline $\begin{array}{c}\mathrm{I}-\mathrm{C} \\
\mathrm{H} \operatorname{Ln} .24 \\
\underset{60 \mathrm{~s}}{\mathrm{O}} \underset{60 \mathrm{~s}}{\mathrm{O}}\end{array}$ & $\begin{array}{l}\text { Bed room Side hall } \\
\text { The traditional structure of } \\
\text { residence was divided into three } \\
\text { segments and walls were built. }\end{array}$ & 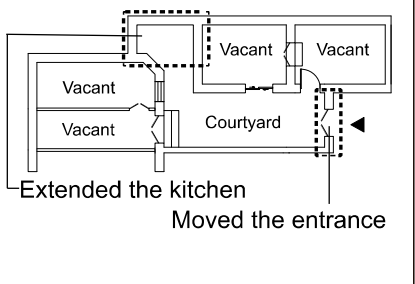 & $\begin{array}{l}\text { Making some } \\
\begin{array}{l}\text { Opened the Put the } \\
\text { homemade local general } \\
\text { shelves on at the store } \\
\text { the street } \\
\text { cortyard }\end{array}\end{array}$ \\
\hline 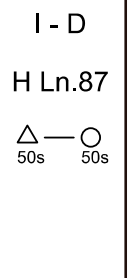 & $\begin{array}{l}\text { In 1950s, The gaverment levied the } \\
\text { shop(Handmade tofu) }\end{array}$ & $\begin{array}{l}\text { In 1990s, The family repurchased } \\
\text { the shop (General store) }\end{array}$ & $\begin{array}{l}\text { Purchas } \\
\text { next doc } \\
\text { it as a b }\end{array}$ \\
\hline $\begin{array}{c}\text { II - B } \\
\text { H Ln.83 }\end{array}$ & $\begin{array}{l}\text { Installed a tabacco shop } \\
\text { In 1960s, newly constracted }\end{array}$ & $\begin{array}{l}\text { Expanded the bedro } \\
\text { the courtyard }\end{array}$ & $\begin{array}{l}\text { Interiors were repaired } \\
\text { Placed chairs on the street } \\
\text { for a cafe the oldest } \\
\text { daughter started. }\end{array}$ \\
\hline 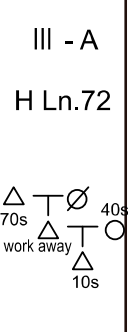 & $\left.\right|_{\substack{\text { Rented out half of the two-story } \\
\text { residence }}} ^{\text {Living }}$ & 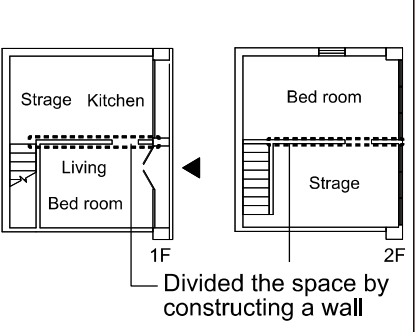 & $\begin{array}{l}\text { Interiors were repaired } \\
\text { Converted to a } \\
\text { shower room in new roof was } \\
\text { installed }\end{array}$ \\
\hline $\begin{array}{c}\text { III - B } \\
\text { H Ln.39 } \\
\underset{60 \text { s }}{\triangle}\end{array}$ & 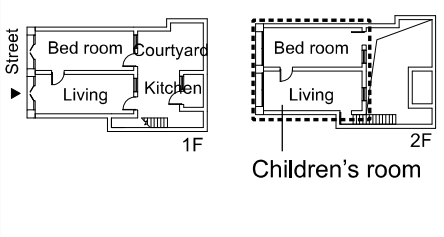 & $\begin{array}{l}\text { Bed room Chess } \\
\text { Put the chess room } \\
\text { and sanitary room } \\
\text { in the courtyard }\end{array}$ & Interiors were repaired \\
\hline 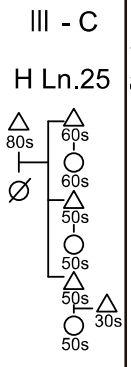 & 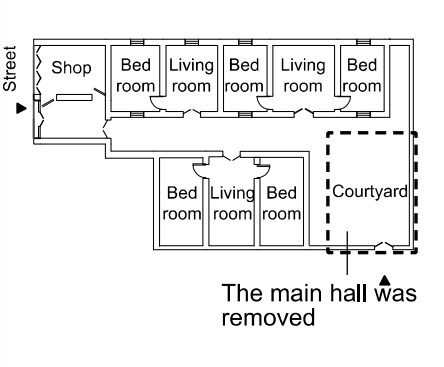 & $\begin{array}{c}\text { Shop } \\
\text { Sed }\end{array}$ & Put the kitchen \\
\hline
\end{tabular}

Figure 4. Characteristics of residential transformation process. 
(2) Pattern II: A pattern where new constructions were made during the government levy period

New constructions during the government levy period are only observed in Type B.

Case II-B "H Ln. 83": This residence was newly constructed when the family moved during the 1960s. Initially, since it had a gate house and a courtyard, it was classified as type B. The courtyard was used as a cooking space. During the 1980s, the family started a tobacco shop, installing a counter and a shelf in the living room, where commercial and living spaces were henceforth mixed. When the head of the family passed away in 1998, the tobacco shop was shut and the space was used as a living space. Immediately prior to the improvement of the old town, aware that new constructions and expansions would be banned following the development, the family expanded the bathroom, kitchen, and bedroom in the courtyard. This turned the courtyard into a room. In addition, when tourism development began in 2007, the bedroom and kitchen interiors were repaired. In 2014, the oldest daughter started a café and placed chairs on the street to utilize the public space.

Owing to the several expansions and changes to functions with regard to everyday needs since the beginning of the construction, it is difficult to infer whether the traditional residential style is maintained as the courtyard was converted to a room. The façade that faces the street is characteristic of residences that constitute the historic district, as is the shop extending outward.

(3) Pattern III: A pattern without large-scale modifications during the government levy period

Pattern III did not feature large-scale modifications during the government levy period, and there are subsequent ongoing modifications in response to the situation of each household.

Case III-A "H Ln. 72": "H Ln. 72" has a spatial structure of Type A. The head of the household became independent after marrying in 1993, and began living in the residence by renting out half of the two-story residence. At the start of the rental period, there was only one space on the first and the second stories, but by dividing the space into left and right wings by constructing a wall, the bedroom, kitchen, and storage could be separated. As the father of the head of the household aged and became home-bound, a part of the bedroom on the first floor was converted to a shower room. In addition, in 2012 and 2014, a new roof was installed to combat dirt and aging and the walls were repainted as well.

Due to the limited area and consequent functional inconveniences, the residents decided to cope with changes to the family situations by modifying the interiors accordingly. Tourism development had little impact on this household.

Case III-B "H LN. 39": "H Ln. 39" has a Type B spatial structure with only a male resident in his 60s living alone. The head of the household was retired and was employed to deliver milk to residents of the old town every morning. Though there was a room for a child on the second floor and a kitchen in the courtyard, the second floor was vacated because his daughter married and moved away in the 2000s. After retirement, he modified the space to create a chess room extending into the courtyard. Routinely, he used the space to chat with his friends and play chess. During the 2007 tourism development drive, the opening, roof, pavement, and walls were repainted.

Expansions during the free construction period and renovation during the governmental development period were made to meet the day-to-day needs of residents. Expansion was possible, due to the availability of a courtyard space. However, traditional spatial structure was not maintained, and there was no response to tourism development.

Case III-C "H Ln. 25": "H Ln. 25" has a Type C spatial structure and houses three generations of the family, with eight members living together. The residence was built during the Qing Dynasty with straw and mud. It is a traditional spatial structure that has a general store operating from the room facing the street, with side halls as bedrooms for the two generations on both sides of the courtyard, and the room for the head of the household at the back of the courtyard. During the 1970s, considering the age and convenience of the residence, the whole residence was reconstructed with bricks. During the reconstruction, the main hall at the far back was removed. During the 1980s, the kitchen was expanded in the back of the courtyard. During the 2000s, there have been repeated reconstructions and expansions with movement of family members. During the 2007 tourism development boom, the interior of the residence was renovated. 
There were enough rooms that could hold the increase in the number of residents. As the residence aged, many repairs and reconstructions were undertaken. There are planned modifications from the viewpoint of living in this residence for the foreseeable future. However, there is no active strategy related to attempt to benefit from tourism.

Though many residences fitting Pattern III did not undergo forcible government-mandated modifications, these residences have a relatively high likelihood of maintaining a traditional spatial structure; however, in reality, there were many modifications to suit the day-to-day needs of residents. During the governmental development period, individual reconstruction and expansion was banned. Thus, in types A and B with limited area, response to future daily needs posed definite challenges.

\section{Discussion}

Considering residential transformations resulting from the modifications made by the residents, traditional spatial structure could not be maintained. In addition, the residents repeatedly reconstructed within a limited area, and there was a decline in the quality of living environments because of, for example, converting the courtyard to a room. The old town improvement plan details measures toward classification and protection of traditional buildings and for increasing tourism; however, examination of the preservation methods that combine improvement of the living environment remain a priority.

In addition, there are several cases in which residencies fell vacant, due to changes in family structure, among others. In the process of securing the quality of living environment and increasing tourism, vacant spaces and their use need to be examined.

In terms of the relationship with tourism, residential modifications were made in the early stage for patterns I and II. Some businesses are developed to attract tourists to traditional spatial structures and parts that face the street. This is an active contribution of residents to tourism development. However, according to a study conducted of residential renovations in response to tourism in Vietnam, commercial activities flourished in areas facing the street. Residents' own modifications to façades and installation of signs have had an impact on the townscape [24]. Conditions must be improved so that the townscape is protected while encouraging residents' tourism-related efforts. By contrast, with Pattern III where the traditional spatial structure is likely to be maintained, there are residential modifications that attach importance to day-to-day needs as well, but not as much to tourism. In a study of residents' awareness of tourism in Nanluoguxiang, Peking, many residents display a passive attitude toward tourism development [25]. In a study about protection of traditional districts in Kanazawa, Japan, rather than the government, it is experts, such as realtors and engineers, who work with the residents together with NPOs at the center, and there is an efficient management system that includes diverse stakeholders in place. For residents, it is important to create awareness that an individual asset, such as a residence, is an element that forms part of the public townscape [26]. In Hexia old town, both the government and experts from Architects \& Engineers Co. Ltd. of Southeast University formulate the plans [27]. However, residents' awareness of the plan is quite low (Table 4). Therefore, measures to increase awareness among residents must be examined.

Tourism offers benefits such that business spaces, such as merchants, appear in the old town. In Hexia old town, with changes in the family structure, households that had hitherto left the old town are resuming business in the old town with increasing tourism. Especially with Pattern I, there were multiple cases where residents made an effort to keep their business and home in close proximity. Such efforts by residents should be examined as a policy to sustain life and work under conditions of building preservation works and limited residential areas. However, at Zhouzhuang old town, continued residence by the next-generation residents is a concern. Therefore, even in Hexia old town, it is essential to make an effort to improve the living environments to ensure continuity of the existing lifestyles and businesses into the next generation.

The old town renovation plan (Hexia old town Historical and Cultural Area Conservation and Improvement Plan) classifies traditional buildings and presents separate conservation policies for 
each type. For example, for buildings designated as Historical and Cultural Site, the spatial structure and building materials are strictly stipulated for carrying out repair and maintenance. On the other hand, for private houses that are in the protection range, but classified as general housing, in principle, the color, decoration, altitude, etc. of the facade part facing the road are defined, but there are no further detailed regulations. Furthermore, as a policy of tourism promotion, items, such as "private homes with ambience of traditional lifestyle" and "sales and production activities of traditional specialties", are taken into consideration, but the relationships with specific examples and building conservation are not indicated.

Therefore, we propose the following items based on the situation of residential renovations by residents elucidated in this study.

(1) Among traditional residential spatial strictures, especially since the house front facing the street (Gate house: Lin jie) is a boundary between public and private spaces, it is a useful element for conservation of buildings and tourism promotion. By establishing regulations that promote active use of not only facades, but also the whole house front, and by supporting repairs, it can become a space where people can appreciate life, commercial, and productive activities from the street. First, we implement renovation of private homes that become models, and aim to increase awareness of residents and improve the ripple effect.

(2) If residential area is small and it is difficult to maintain the space suited for tourism, renovations that focus on improved living environment are promoted instead of banning all renovations. Especially, the conditions are that appearance from the street is maintained, and that sanitary environment within residences is improved.

(3) As a plan to use vacant houses, efforts are made to encourage participation of residents who are not able to open their own homes to tourists in ways, such as making repairs as a base for experience type tourism, with its operation shared by community residents.

\section{Conclusions}

This study analyzed the characteristics of spatial structure of residences in Hexia old town, China and the transformations associated with tourist development, drawing the following conclusions:

(1) In Hexia old town, the government spearheaded tourism development in 2007, leading to renovation of façades of traditional houses and the residents modifying the interiors to suit their daily lifestyles.

(2) Residences in Hexia old town can be classified into four types based on the spatial structure of traditional houses. In addition to relatively large-scale structures with a courtyard, there are comparatively small structures comprising buildings that are extended to the area facing the street and the courtyard.

(3) Residential transformations in Hexia old town can be classified into three stages: The government levy period, the free construction period, and the governmental development stage. Residential modification processes during these periods display that modifications can be further classified into three patterns. In all the patterns, residential modifications were made during the free construction period and the governmental development period.

(4) Awareness of protection standards for traditional buildings among government representatives is low, and residential modifications continue in response to day-to-day needs in accordance with the governmental development period. However, the balance between protection of traditional buildings and improvement of living environments is a concern.

(5) Since a ban on residential modifications is imposed on small residential buildings in the form of the protection regulations for traditional buildings, response to day-to-day needs becomes a challenge. 
(6) With tourism development, businesses have started to use part of the remaining traditional houses or vacant rooms, and as a result sustainability of residents' lifestyles by keeping the residence and work in close proximity in Hexia old town is expected.

To integrate building protection by the government, tourism development, and needs of residents in the improvement plan for the old town, it is necessary to grasp the concerns regarding the living environments, due to residential modifications made by residents, and to increase the residents' awareness of the significance of protecting traditional buildings by gaining understanding of not only the price of buildings, but also the potential for sustainability of lifestyle and businesses in the old town.

In this study, we analyzed processes of conservation, renovation, and tourism development from the viewpoint of residents of the old town, but also evaluation from the viewpoint of tourists is necessary. We will make future research on compatibility between charm for tourists and residents' living.

Author Contributions: Conceptualization, R.N., S.S. and S.M.; Methodology, R.N., S.S. and S.M.; Validation, R.N., S.S. and S.M.; Formal Analysis, R.N., S.S.; Investigation, S.S.; Resources, R.N. and S.S.; Data Curation, R.N. and S.S.; Writing-Original Draft Preparation, R.N. and S.S.; Writing-Review and Editing, R.N., S.S. and S.M.; Visualization, R.N. and S.S.; Supervision, R.N. and S.M.; Funding Acquisition, R.N. and S.M.

Funding: The part of this research was funded by JSPS KAKENHI grant number 16K06628.

Acknowledgments: The investigation of this research was supported by Hokkaido Univ. Lab. of Architecture and Planning (S.M.).

Conflicts of Interest: The authors declare no conflict of interest.

\section{References}

1. Whitehand, J.W.R.; Gu, K. Urban conservation in China: Historical development, current practice and morphological approach. Town Plan. Rev. 2007, 78, 643-670. [CrossRef]

2. Bian, X. Comparison among tourism protection and development models of Jiangsu and Zhejiang ancients' towns. Urban Probl. 2010, 12, 50-55. (In Chinese)

3. Ruan, Y.; Yuan, F. Conservation and Development of the Historic Water Towns in the South of Yangtze River. Urban Plan. Forum. 2008, 5, 52-59. (In Chinese)

4. Su, X. Heritage Production and Urban Locational Policy in Lijiang, China. Int. J. Urban Reg. Res. 2011, 35, 1118-1132. [CrossRef]

5. Xie, S.; Zhang, X.; Li, Y.; Skitmore, M. Echoes of Italian lessons on the typo-morphological approach: A planning proposal for Gulangyu Island, China. Habitat Int. 2017, 69, 1-17. [CrossRef]

6. Xie, J.; Heath, T. Conservation and revitalization of historic streets in China: Pingjiang Street, Suzhou. J. Urban Des. 2017, 22, 455-476. [CrossRef]

7. Su, M.; Wall, G.; Xu, K. Heritage tourism and livelihood sustainability of a resettled rural community: Mount Sanqingshan World Heritage Site, China. J. Sustain. Tour. 2016, 24, 735-757. [CrossRef]

8. Throsby, D. Investment in urban heritage conservation in developing countries: Concepts, methods and data. City Cult. Soc. 2016, 7, 81-86. [CrossRef]

9. García-Hernández, M.; Calle-Vaquero, M.; Yubero, C. Cultural heritage and urban tourism: Historic city centres under pressure. Sustainability 2017, 9, 1346. [CrossRef]

10. Zhou, T.; Zhou, Y.; Liu, G. Comparison of critical success paths for historic district renovation and redevelopment projects in China. Habitat Int. 2017, 67, 54-68. [CrossRef]

11. Shepherd, R. UNESCO's Tangled Web of Preservation: Community, Heritage and Development in China. J. Contemp. Asia 2017, 47, 557-574. [CrossRef]

12. Han, F.; Yang, Z.; Shi, H.; Wall, G. How to Promote Sustainable Relationships between Heritage Conservation and Community, Based on a Survey. Sustainability 2016, 8, 886. [CrossRef]

13. Ren, W.; Han, F. Indicators for Assessing the Sustainability of Built Heritage Attractions: An Anglo-Chinese Study. Sustainability 2018, 10, 2504. [CrossRef] 
14. Feng, X.; Yamazaki, J. Development of historic town(village) conservation system and the modern planning case in P. R. China: Focus on Plain Conservation after 1980. J. Archit. Plan. 2013, 78, 373-382. (In Japanese) [CrossRef]

15. Feng, X.; Yamazaki, J. Study on conservation development and conservation planning characteristic of historic town(village) in southwest of P. R. China. J. Archit. Plan. 2013, 78, 2513-2520. [CrossRef]

16. Zhou, J. Brief talk about development and preservation of Hexia old town. Sci. Technol. Inf. 2011, 30, $173-174$. (In Chinese)

17. Jin, M.; Huang, Z.; Yu, W. Conservation and renovation of Huaian Hexia Old town under the context of the Grand Canal culture. Design 2017, 17, 154-155. (In Chinese)

18. Zhu, Y.; Yan, Y.; Zheng, F.; Ge, J.; Gu, Y. Research on the renovation of historical buildings and improvement of the residential environment of Hangzhou Zhuyangxin plaster store. J. Asian Archit. Build. Eng. 2010, 9 , 395-402. [CrossRef]

19. Fujiki, Y.; Kashihara, H.; Yamamura, T. The impact of the use of traditional houses by becoming tourist site: A case of the world heritage site, the old town of Lijiang, Yunnan province, China. J. Archit. Plan. 2008, 73, 1499-1506. [CrossRef]

20. The Culture and History Commitiee of Huai'an Political Consultative Conference. Hexia Old Town (Guzhen Hexia); Chinese Cultural and Historical Press: Beijing, China, 2010. (In Chinese)

21. Huai'an City Planning Bureau. Draft of Huaian Historical and Cultural Famous Town Conservation Plan. Available online: http://ghj.huaian.gov.cn/ghgs/ghbzcg/csghbzgs/ghbzfapqgg/content/ ff8080813052091101343a7480923be0.html (accessed on 1 September 2018).

22. Huai'an City, Draft of Hexia Old Town North Entrance Planning and Design. Available online: http:/ / www. huaian.gov.cn/gzcy/myzj/content/402881f851a156a40151a161ca920bca.html (accessed on 1 September 2018).

23. Huai'an City Planning Bureau. Draft of Hexia Old Town Historical and Cultural Area Conservation Plan. Available online: http:/ /ghj.huaian.gov.cn/ghgs/ghbzphgs/content/5e38cfb855ee00060156075eb80332c9. html (accessed on 1 September 2018).

24. Utsumi, S. Influence of the Tourism Business on the Facades of Townhouses in the Case of Hanoi's Ancient Quarter. J. Asian Archit. Build. Eng. 2017, 16, 573-579. [CrossRef]

25. Dai, L.; Wang, S.; Xu, J.; Wan, L.; Wu, B. Qualitative Analysis of Residents' Perceptions of Tourism Impacts on Historic Districts: A Case Study of Nanluoguxiang in Beijing, China. J. Asian Archit. Build. Eng. 2017, 16, 107-114. [CrossRef]

26. Jang, M.; Park, S.; Lee, M. Conservation Management of Historical Assets Through Community Involvement: A Case Study of Kanazawa Machiya in Japan. J. Asian Archit. Build. Eng. 2017, 16, 53-60. [CrossRef]

27. Zhang, Q. Huaian Section of Beijing-Hangzhou Grand Canal: Protection and Utilization of Its Cultural Heritage. J. Nanjing Norm. Univ. 2013, 2, 60-70. (In Chinese) 